\author{
ACTA MYCOLOGICA \\ Vol. 47 (1): 65-73 \\ 2012
}

\title{
Impact of light on yielding of some Pleurotus sp. strains
}

\author{
MAREK SIWULSKI, MIROSŁAWA ZIOMBRA and KRZYSZTOF SOBIERALSKI
}

Department of Vegetable Crops, Poznań University of Life Sciences

Dąbrowskiego 159, PL-60-594 Poznań, fungus@up.poznan.pl

Siwulski M., Ziombra M., Sobieralski K. Impact of light on yielding of some Pleurotus sp. strains. Acta Mycol. 47 (1): 65-73, 2012.

Light is an important factor deciding about yielding and morphological characters of Pleurotus carpophores. The objective of the research was to ascertain the impact of period and intensity of lighting on yielding and carpophore morphological features of four strains of oyster mushroom. The following strains were investigated: P. ostreatus: PX, K22 and P80 strains, P. pulmonarius: P20 strain. Fluorescent lamps with Day-Light were used to provide light in the cultivation room. The following lighting periods were used: 6,10 and 14 hours/ day and the applied lighting intensity included: 100, 300, 500 and 700 lx. Lighting exerted a significant impact on yielding. The highest carpophore crop was recorded when the applied lighting intensity was 500 and $700 \mathrm{~lx}$ for the period of $14 \mathrm{~h} / \mathrm{d}$. The highest mean mass of carpophores was recorded at 14-hour light exposure and 500 and 700 lx lighting intensity. Carpophore morphological features modified by the lighting period and its intensity included the cap diameter as well as the length and thickness of the stem.

Key words: oyster mushroom, cultivation, lighting intensity, carpophore, morphological traits

\section{INTRODUCTION}

Species from the Pleurotus genus, including their strains, differ with regard to characters of their carpophores (Ziombra, Gembiak 2000; Siwulski et al. 2006). Yields of mushrooms from the Pleurotus genus depend on many factors; apart from genetic properties, also environmental factors play a significant role in this regard (Lelley 1991; Shah et al. 2004).

The mycelium of mushrooms from the Pleurotus genus does not require light for its growth (Sharma 2004), nevertheless, light is necessary for the proper development of carpophores (Olivier 1988; Royse, Zaki 1991). Trukhonovets (1991) maintains that during the period of carpophore development and growth, light is an important factor deciding about yielding and morphological characters of fruiting 
bodies. Experiments conducted by the above-mentioned researcher showed that light quantities required for carpophore development can be regulated by shortening the exposure time and increasing the light intensity or, conversely, by lengthening the time of exposure to light and decreasing its intensity. In other words, the total quantity of light is decisive for normal development of carpophores. It should, however, be emphasised that there are significant differences between strains. Selection of profusely fruiting strains and providing optimal conditions for their cultivation are commonly considered to be among key yield-forming factors.

Due to considerable variability of the Pleurotus genus, both with regard to morphological as well as functional features, many forms of this mushroom have already been selected and are used in cultivation as separate strains. Strains differ among one another with regard to the weight of their carpophores, size and thickness of the pileus as well as the length and thickness of the stem. These traits alter depending on cultivation conditions, although they remain characteristic for the given strain (Curvetto et al. 2002; Siwulski et al. 2006).

The objective of the presented research project was to ascertain the impact of light on yielding and carpophore morphological features of four strains of oyster mushroom.

\section{MATERIAL AND METHODS}

The following species and strains of oyster mushroom were investigated: Pleurotus ostreatus Jacq.ex.(Fr.) Kumm. - PX, K22 and P80 strains, Pleurotus pulmonarius (Fr.) Quel. - P20 strain. The evaluation of yields depending on the duration and intensity of lighting exposure was carried out in air-conditioned chambers of the Department of Vegetable Crops, University of Life Sciences in Poznań. The experiment was set up in a random design in four replications and two cultivation cycles.

The cultivation substrate was wheat straw cut into chaff of 3-5 cm length. The substrate of approximately $70 \%$ moisture content was pasteurised at the temperature of $60^{\circ} \mathrm{C}$ for the period of 48 hours. After the pasteurisation process, the substrate was cooled down to the temperature of $25^{\circ} \mathrm{C}$ and mixed with oyster mushroom mycelium. The oyster mushroom mycelium as propagation material was produced on wheat grain. The proportion of the applied mycelium in relation to the cultivation substrate was established at $5 \%$. The substrate, together with oyster mushroom mycelium, were placed in perforated polyethylene bags; $10 \mathrm{dm}^{3}$ in each bag.

The process of overgrowing of the oyster mushroom mycelium through the substrate took place in darkness in a cultivation facility in which the temperature was maintained at the level of $18-20^{\circ} \mathrm{C}$ and air humidity - at $80-85 \%$.

Once the substrate was overgrown by the mycelium of the examined strains, different lighting conditions were applied for the cropping period. Fluorescent lamps with light similar to natural light (Day-Light) were used to provide light in the facilities. The following lighting periods were used: 6,10 and 14 hours/day and the applied lighting intensity included: 100, 300, 500 and $700 \mathrm{~lx}$. Measurements of the 
lighting intensity were performed on the substrate surface with the assistance of a luxmeter L-20.

The yield mass in relation to the substrate dry matter was determined and biometric measurements of fruiting bodies were taken. A sample for biometric measurements consisting of 40 carpophores was collected randomly from each experimental combination. The diameter and thickness of the cap and length and thickness of the stem were determined. The results comprising yields and morphological traits of carpophores were analysed for mean values from replications and cultivation cycles. The analysis of variance for three-factorial experiments was performed calculating LSD at the significance level of $\alpha=0.05$.

\section{RESULTS}

Lighting exerted a significant impact on yielding. The highest carpophore crop, irrespective of the strain, was recorded in combinations where the applied lighting intensity was 500 and $700 \mathrm{~lx}$ for the period of $14 \mathrm{~h} / \mathrm{d}$. The experimental strains responded differently to the applied light regimes. At lighting intensity of 500 and 700 $\mathrm{lx}$, the highest and non-significantly differing crops were recorded for PX, K22 and P80 strains, whereas P20 strain exhibited the weakest response to changes in the lighting intensity, especially at 14-hour light exposure (Tab. 1).

The light exposure of $6 \mathrm{~h} / \mathrm{d}$, irrespective of the lighting intensity, resulted in a significant decline of yields in comparison with 10 and $14 \mathrm{~h} / \mathrm{d}$ lighting period. The highest yields were obtained at 14-hour light exposure. Apart from the duration of the light exposure, also light intensity played a significant role. The highest crops were recorded at 500 and $700 \mathrm{~lx}$ lighting intensity. Yields obtained in such conditions did not differ significantly irrespective of the period of lighting.

Table 1

Pleurotus yield in relation to intensity and period of lighting ( $\mathrm{g} \mathrm{x} \mathrm{kg}^{-1}$ D.M. of substrate)

\begin{tabular}{|c|c|c|c|c|c|}
\hline \multicolumn{2}{|c|}{ Lighting } & \multicolumn{4}{|c|}{ Strain } \\
\hline (h) & (lx) & PX & P20 & K22 & B80 \\
\hline \multirow[t]{4}{*}{6} & 100 & 188 & 205 & 122 & 182 \\
\hline & 300 & 206 & 275 & 138 & 235 \\
\hline & 500 & 278 & 290 & 245 & 285 \\
\hline & 700 & 346 & 330 & 282 & 296 \\
\hline \multicolumn{2}{|c|}{ Mean } & 256 & 275 & 196 & 250 \\
\hline \multirow[t]{4}{*}{10} & 100 & 228 & 402 & 232 & 330 \\
\hline & 300 & 380 & 518 & 326 & 462 \\
\hline & 500 & 512 & 622 & 480 & 634 \\
\hline & 700 & 522 & 635 & 492 & 780 \\
\hline \multicolumn{2}{|c|}{ Mean } & 411 & 544 & 382 & 552 \\
\hline \multirow[t]{4}{*}{14} & 100 & 426 & 532 & 284 & 325 \\
\hline & 300 & 595 & 660 & 398 & 554 \\
\hline & 500 & 805 & 668 & 615 & 890 \\
\hline & 700 & 830 & 672 & 728 & 912 \\
\hline \multicolumn{2}{|c|}{ Mean } & 664 & 633 & 506 & 670 \\
\hline
\end{tabular}


It was demonstrated on the basis of analyses of lighting intensity and time interrelationships that it was not possible to shorten the time of light exposure even when light intensity was increased up to $700 \mathrm{~lx}$. On the other hand, it is not advisable to reduce lighting intensity below $500 \mathrm{~lx}$, if we want to lengthen the duration of light exposure at the expense of lighting intensity. The examined strains responded similarly to lighting duration in the 24-hour period.

The recorded mean carpophore mass characteristic for a given strain changed following different light exposure of the cultivation. When a 14-hour lighting regime was employed, the mean weight of harvested carpophores was higher in comparison with fruiting bodies grown in 6 or 10-hour regimes. The mean carpophore weight increased together with the length of the lighting period per day. Also lighting intensity exerted influence on carpophore weight. When the applied lighting intensity was 100 or $300 \mathrm{~lx}$, carpophores of significantly smaller weight were obtained than at

Table 2

Carpophore mean mass of Pleurotus strains in relation to intensity and period of lighting ( $\mathrm{g}$ )

\begin{tabular}{|c|c|c|c|c|c|}
\hline \multicolumn{2}{|c|}{ Lighting } & \multicolumn{4}{|c|}{ Strain } \\
\hline (h) & (lx) & PX & $\mathrm{P} 20$ & K22 & B80 \\
\hline 6 & $\begin{array}{l}100 \\
300 \\
500 \\
700\end{array}$ & $\begin{array}{l}22 \\
28 \\
36 \\
42\end{array}$ & $\begin{array}{l}28 \\
32 \\
32 \\
32\end{array}$ & $\begin{array}{l}20 \\
20 \\
22 \\
24\end{array}$ & $\begin{array}{l}26 \\
28 \\
40 \\
42\end{array}$ \\
\hline \multicolumn{2}{|c|}{ Mean } & 32 & 31 & 22 & 34 \\
\hline 10 & $\begin{array}{l}100 \\
300 \\
500 \\
700\end{array}$ & $\begin{array}{l}38 \\
42 \\
48 \\
50\end{array}$ & $\begin{array}{l}34 \\
36 \\
38 \\
38\end{array}$ & $\begin{array}{l}24 \\
36 \\
38 \\
38 \\
\end{array}$ & $\begin{array}{l}32 \\
44 \\
46 \\
48\end{array}$ \\
\hline \multicolumn{2}{|c|}{ Mean } & 45 & 37 & 34 & 43 \\
\hline 14 & $\begin{array}{l}100 \\
300 \\
500 \\
700\end{array}$ & $\begin{array}{l}40 \\
58 \\
66 \\
68\end{array}$ & $\begin{array}{l}24 \\
36 \\
48 \\
50\end{array}$ & $\begin{array}{l}24 \\
34 \\
48 \\
50\end{array}$ & $\begin{array}{l}36 \\
50 \\
58 \\
60\end{array}$ \\
\hline \multicolumn{2}{|c|}{ Mean } & 58 & 40 & 39 & 51 \\
\hline
\end{tabular}

Table 3

Cap diameter of Pleurotus strains in relation to intensity and period of lighting $(\mathrm{mm})$

\begin{tabular}{|c|c|c|c|c|c|}
\hline \multicolumn{2}{|c|}{ Lighting } & \multicolumn{4}{|c|}{ Strain } \\
\hline (h) & (lx) & PX & P20 & K22 & B80 \\
\hline 6 & $\begin{array}{l}100 \\
300 \\
500 \\
700\end{array}$ & $\begin{array}{l}22 \\
30 \\
36 \\
34\end{array}$ & $\begin{array}{l}30 \\
32 \\
36 \\
38\end{array}$ & $\begin{array}{l}18 \\
20 \\
26 \\
26\end{array}$ & $\begin{array}{l}22 \\
22 \\
28 \\
32\end{array}$ \\
\hline \multicolumn{2}{|c|}{ Mean } & 31 & 34 & 23 & 26 \\
\hline 10 & $\begin{array}{l}100 \\
300 \\
500 \\
700\end{array}$ & $\begin{array}{l}32 \\
42 \\
50 \\
53\end{array}$ & $\begin{array}{l}42 \\
52 \\
52 \\
52\end{array}$ & $\begin{array}{l}24 \\
32 \\
37 \\
38 \\
\end{array}$ & $\begin{array}{l}28 \\
38 \\
46 \\
46\end{array}$ \\
\hline \multicolumn{2}{|c|}{ Mean } & 44 & 50 & 33 & 40 \\
\hline 14 & $\begin{array}{l}100 \\
300 \\
500 \\
700\end{array}$ & $\begin{array}{l}38 \\
56 \\
72 \\
74 \\
\end{array}$ & $\begin{array}{l}46 \\
48 \\
52 \\
52 \\
\end{array}$ & $\begin{array}{l}28 \\
38 \\
47 \\
52 \\
\end{array}$ & $\begin{array}{l}32 \\
46 \\
58 \\
62 \\
\end{array}$ \\
\hline \multicolumn{2}{|c|}{ Mean } & 60 & 50 & 41 & 50 \\
\hline
\end{tabular}


the same period to light exposure but of 500 and 700 lx. However, lighting intensity of 500 and $700 \mathrm{~lx}$ applied only for 6 or 10 hours exerted a negative influence on carpophore weight. The highest weight of fruiting bodies was recorded at 14-hour light exposure and 500 and 700 lx lighting intensity (Tab. 2). Strain P20 was characterised by the weakest response to changes in lighting conditions. The remaining strains were found to respond similarly to changes in both lighting intensity and duration.

Cap diameter and thickness were features characteristic for a given strain and, similarly to the carpophore mass, depended on lighting intensity and duration. Carpophores with the largest and thickest caps were observed in combinations with 14 h/d light exposure and 500 and 700 lx lighting intensity (Tabs 3 and 4).

The applied lighting intensity of cultivations affected the length and diameter of mushroom stems (Tabs 5 and 6). Fruiting bodies with the shortest stems were found in strains cultivated for the longest light exposure $(14 \mathrm{~h} / \mathrm{d})$. In addition, a distinct

Table 4

Cap thickness of Pleurotus strains in relation to intensity and period of lighting (mm)

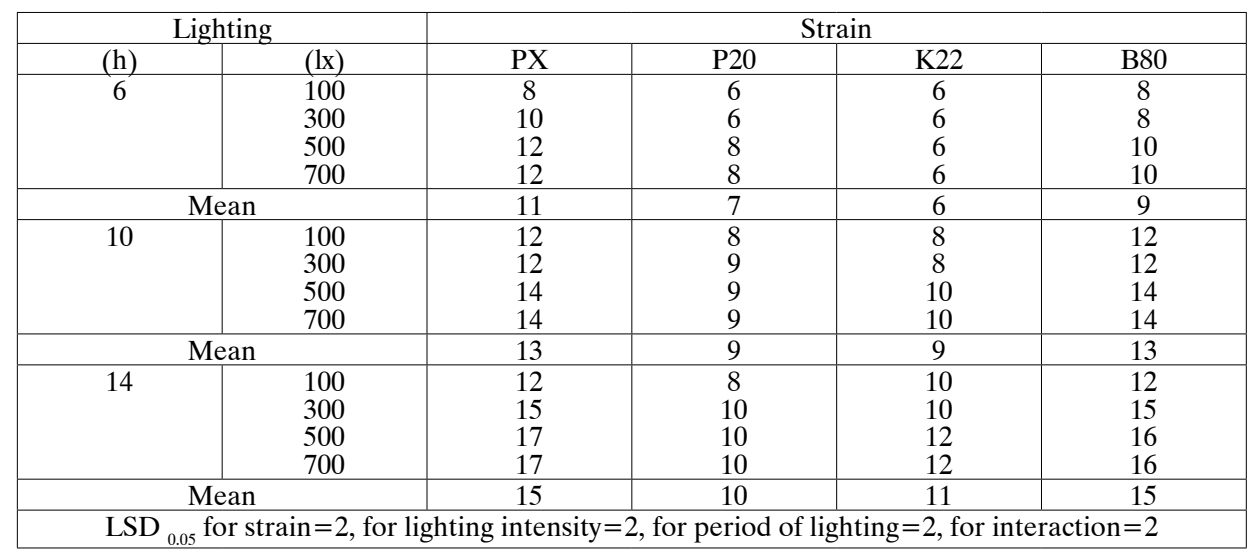

Table 5

Stem length of Pleurotus strains in relation to intensity and period of lighting ( $\mathrm{mm}$ )

\begin{tabular}{|c|c|c|c|c|c|}
\hline \multicolumn{2}{|c|}{ Lighting } & \multicolumn{4}{|c|}{ Strain } \\
\hline (h) & (lx) & PX & $\mathrm{P} 20$ & K22 & B80 \\
\hline \multirow[t]{4}{*}{6} & 100 & 40 & 14 & 38 & 38 \\
\hline & 300 & 38 & 14 & 38 & 36 \\
\hline & 500 & 36 & 12 & 34 & 34 \\
\hline & 700 & 36 & 12 & 34 & 34 \\
\hline \multicolumn{2}{|c|}{ Mean } & 38 & 13 & 36 & 35 \\
\hline \multirow[t]{4}{*}{10} & 100 & 40 & 14 & 36 & 34 \\
\hline & 300 & 36 & 12 & 34 & 32 \\
\hline & 500 & 34 & 12 & 33 & 28 \\
\hline & 700 & 32 & 10 & 33 & 26 \\
\hline \multicolumn{2}{|c|}{ Mean } & 36 & 12 & 34 & 30 \\
\hline \multirow[t]{4}{*}{14} & 100 & 36 & 12 & 34 & 34 \\
\hline & 300 & 32 & 10 & 26 & 28 \\
\hline & 500 & 28 & 10 & 25 & 26 \\
\hline & 700 & 26 & 10 & 25 & 26 \\
\hline \multicolumn{2}{|c|}{ Mean } & 31 & 11 & 28 & 28 \\
\hline
\end{tabular}


Table 6

Stem diameter of Pleurotus strains in relation to intensity and period of lighting $(\mathrm{mm})$

\begin{tabular}{|c|c|c|c|c|c|}
\hline \multicolumn{2}{|c|}{ Lighting } & \multicolumn{4}{|c|}{ Strain } \\
\hline (h) & (lx) & PX & $\mathrm{P} 20$ & K22 & B80 \\
\hline \multirow[t]{4}{*}{6} & 100 & 8 & 8 & 8 & 9 \\
\hline & 300 & 8 & 8 & 8 & 9 \\
\hline & 500 & 8 & 10 & 9 & 11 \\
\hline & 700 & 9 & 10 & 10 & 11 \\
\hline \multicolumn{2}{|c|}{ Mean } & 8 & 9 & 9 & 10 \\
\hline \multirow[t]{4}{*}{10} & 100 & 9 & 10 & 8 & 8 \\
\hline & 300 & 10 & 10 & 9 & 8 \\
\hline & 500 & 10 & 10 & 10 & 10 \\
\hline & 700 & 12 & 10 & 10 & 10 \\
\hline \multicolumn{2}{|c|}{ Mean } & 10 & 10 & 9 & 9 \\
\hline \multirow[t]{4}{*}{14} & 100 & 10 & 10 & 8 & 8 \\
\hline & 300 & 12 & 12 & 8 & 8 \\
\hline & 500 & 14 & 12 & 10 & 10 \\
\hline & 700 & 14 & 12 & 10 & 10 \\
\hline \multicolumn{2}{|c|}{ Mean } & 13 & 12 & 9 & 9 \\
\hline
\end{tabular}

Table 7

Proportion of stem in carpophore mass of Pleurotus strains in relation to intensity and period of lighting (\%)

\begin{tabular}{|c|c|c|c|c|c|}
\hline \multicolumn{2}{|c|}{ Lighting } & \multicolumn{4}{|c|}{ Strain } \\
\hline (h) & (lx) & PX & P20 & K22 & B80 \\
\hline \multirow[t]{4}{*}{6} & 100 & 42 & 16 & 36 & 40 \\
\hline & 300 & 38 & 16 & 36 & 36 \\
\hline & 500 & 36 & 14 & 32 & 34 \\
\hline & 700 & 36 & 14 & 32 & 30 \\
\hline \multicolumn{2}{|c|}{ Mean } & 38 & 15 & 34 & 35 \\
\hline \multirow[t]{4}{*}{10} & 100 & 38 & 15 & 36 & 34 \\
\hline & 300 & 35 & 14 & 36 & 32 \\
\hline & 500 & 30 & 12 & 30 & 30 \\
\hline & 700 & 28 & 12 & 30 & 30 \\
\hline \multicolumn{2}{|c|}{ Mean } & 33 & 13 & 33 & 32 \\
\hline \multirow[t]{4}{*}{14} & 100 & 33 & 13 & 32 & 28 \\
\hline & 300 & 30 & 12 & 30 & 26 \\
\hline & 500 & 27 & 11 & 27 & 26 \\
\hline & 700 & 27 & 11 & 27 & 25 \\
\hline \multicolumn{2}{|c|}{ Mean } & 29 & 12 & 29 & 26 \\
\hline
\end{tabular}

tendency was found with decreasing lighting intensity for the development of carpophores with increasingly long stems. The stem thickness of carpophores declined with decreasing lighting intensity and shortening of time exposure to light.

The proportion of stems in the weight of carpophores ranged from 11 to $42 \%$ depending on strain, lighting intensity and light exposure time. P20 strain was characterised by the smallest proportion (11-16\%) of stems in carpophores; short stems are typical for this strain and in comparison with other strains, the length of their stems is least dependent on variations in lighting. In the case of the remaining strains, the percentage proportion of the stem weight in the carpophore weight was considerably higher ranging from 25 to $42 \%$, depending on the lighting regime. In general, it can be said that the better the lighting conditions, the smaller was the proportion of the stem weight in the carpophore weight. It is true that when lighting conditions 
deteriorated, the stem also became thinner but it also became longer and this caused that the stem weight increased affecting its percentage proportion in the carpophore weight (Tab. 7).

\section{DISCUSSION}

Light, along with other external factors, exerts a significant impact on the growth and development processes of carpophores of mushrooms from the Pleurotus genus. It acts as a signal triggering off various biophysical and biochemical processes ultimately leading to morphological and phototrophic reactions (Trukhonovets 1991).

In the performed investigations, the size and thickness of the cap and length and thickness of the carpophore stem characteristic for the strain altered under the influence of the applied various lighting regimes. The mean carpophore weight was a trait characteristic for a given strain but dependent on time and intensity of lighting of cultivations.

Also Trukhonovets (1991) reported a dependence of the size of the cap and stem length on lighting intensity. Among important characters affecting salability of fruiting bodies is the ratio of the cap size to the stem size. Stems of carpophores of the majority of oyster mushroom species, with the exception of Pleurotus eryngii, are inedible and should be as small as possible. In our investigations, irrespective of the applied lighting regime, the shortest stems were determined in the case of carpophores of the P20 strain, whereas in the remaining examined strains stems were longer and changed depending on lighting intensity.

However, according to literature data, there is no agreement as to the optimal range of lighting intensity recommended in the mushroom cultivation of Pleurotus genus and, depending on individual researchers, this range fluctuates from 300 to 1500 lx (Lelley 1991; Stamets 2000; Oei 2003; Ziombra et al. 2008).

In the presented experiments, the optimal lighting intensity to obtain high crops of advantageous carpophore morphological features ranged from 500 to $700 \mathrm{~lx}$ for PX, K22 and B80 strains. The examined P20 strain was characterized by the lowest requirements regarding the applied lighting regimes and gave similarly high yields both at 300 and 700 lx lighting intensity. Carpophore morphological traits of the P20 strain remained unchanged throughout the examined range of lighting intensity.

The appropriate growth of fruiting bodies is also affected by the length of the lighting period in the $24 \mathrm{~h}$ rhythm (Trukhonovets 1991). The research results obtained in this study indicate that the applied $14 \mathrm{~h}$ lighting regime turned out to be the most favourable for carpophore development. Crops harvested following the $8 \mathrm{~h}$ light regime were lower than in the case of $10 \mathrm{~h}$ and $14 \mathrm{~h}$ light exposure despite the application of higher lighting intensity of 500 and $700 \mathrm{~lx}$.

Recapitulating, it was concluded on the basis of the performed experiments that cultivations of the examined species of mushrooms from the Pleurotus genus should receive, during the period of the development and growth of fruiting bodies not less than 10 hours of light per $24 \mathrm{~h}$. In order to obtain carpophores of large caps and short stems, the lighting intensity should not be lower than $500 \mathrm{~lx}$. In addition, the 
obtained research results showed that a longer lighting period within the $24 \mathrm{~h}$ period failed to compensate insufficient lighting intensity and, conversely, despite high intensity of lighting, shortening of the lighting exposure time below 10 hours/day is not recommendable.

\section{CONCLUSIONS}

1. The highest yields of PX, K22 and B80 strains of oyster mushroom were obtained from cultivations exposed to 10 and 14 hours of light per $24 \mathrm{~h}$ applying 500 and 700 lx lighting intensity.

2. The P20 strain of oyster mushroom gave similar yields at lighting intensity ranging from 300 through 500 up to $700 \mathrm{~lx}$.

3. The examined oyster mushroom strains developed carpophores with largest caps within the range of lighting considered as optimal to obtain abundant crops.

4. Carpophore morphological features modified by the length of the lighting period and its intensity included the cap diameter as well as the length and thickness of the stem.

\section{REFERENCES}

Curvetto N. R., Figlas D., Devalis R., Delmastro S. 2002. Growth and productivity of different Pleurotus ostreatus strains on sunflower seed hulls supplemented with $\mathrm{N}_{-} \mathrm{NH}_{4}+$ and/or Mn (II). Bioresource Technology 84(2): 171-176.

Lelley J. 1991. Pilzanbau. Biotechnologie der Kulturspeisepilze. Ulmer, Stuttgart, 404 pp.

Oei P. 2003. Mushroom cultivation. Backhuys Publishers Leiden, Netherlands, 429 pp.

Olivier J. M. 1988. Les besoins en lumiere dans la culture des Pleurotes. Bull. Fed. Nat. Syndicate Agricol. Cult. Champignons 40: 1433-1439.

Royse D. I., Zaki S. A. 1991. Yield stimulation of Pleurotus sp. by dual nutrient supplementation of pasteurized wheat straw. (In:) M.J. Maher (ed.). Science and cultivation of edible fungi. Balkema, Rotterdam: 545-547.

Shah Z. A., Ashraf M., Ishtiag M. 2004. Comparative study on cultivatin and yield performance of oyster mushroom (Pleurotus ostreatus) on different substrates. Pakistan J. Nutrition 3 (3): 158-160.

Sharma B. B. 2004. Effect of duration of light on radial growth of pink oyster mushroom. Indian Pathology 57 (2): 234.

Siwulski M., Sobieralski K., Ławicka K. 2006. Porównanie plonowania wybranych odmian i krzyżówek boczniaka Pleurotus sp. Folia Horticulturae, Supl. 2: 130-133.

Stamets P. 2000. Growing Gourmet and Medicinal Mushrooms. Ten Speed Press, Berkeley, pp.574.

Tan Q., Wang ZQ., Cheng JH., Guo Q., Guo L. 2005. Cultivation of Pleurotus spp. in China. Acta Edulis Fungi 12: 338-342.

Trukhonovets V. V. 1991. Effect of illumination intensity on the formation of fruiting bodies in Pleurotus ostreatus (Jacq. Fr.) Kumm. Ukr. Bot. Zh. 48 (2): 67-72.

Ziombra M., Gembiak R. 2000. Cechy morfologiczne owocników grzybów z rodzaju Pleurotus sp. Rocz. AR Pozn. 31: 573-577.

Ziombra M., Czerwińska-Nowak A., Ławicka K. 2008. Wpływ natężenia światła i czasu oświetlenia na plon i cechy morfologiczne owocników kilku odmian boczniaka. Zeszyty Problemowe Postępów Nauk Rolniczych 527: 335-341. 
Wpływ światła na plonowanie kilku ras Pleurotus sp.

\section{Streszczenie}

Światło jest ważnym czynnikiem decydującym o plonowaniu i cechach morfologicznych owocników boczniaka. Celem badań było określenie wpływu czasu i natężenia oświetlenia na wielkość plonu oraz cechy morfologiczne owocników czterech ras boczniaka. Przedmiotem badań były rasy Pleurotus ostreatus: PX, K22 i P80 oraz rasa Pleurotus pulmonarius:P20. Do oświetlenia pomieszczeń uprawowych użyto lamp fluoroscencyjnych o świetle zbliżonym do naturalnego. Okres oświetlenia wynosił 6, 10 i 14 godzin na dobę. Zastosowano oświetlenie o natężeniu 100, 300, 500 i 700 lx. Stwierdzono, że światło wywierało znaczący wpływ na plonowanie. Największe plony owocników uzyskano stosując oświetlenie o natężeniu 500 i 700 lx przez 14 godzin na dobę. Cechami morfologicznymi owocników modyfikowanymi przez długość okresu oświetlenia i jego intensywność były średnica kapelusza oraz długość i grubość trzonu. 